\title{
A manifesto for shadow places: Re-imagining and co-producing connections for justice in an era of climate change
}

EPE: Nature and Space $0(0)|-2|$ (C) The Author(s) 2020 Article reuse guidelines: sagepub.com/journals-permissions DOI: $10.1177 / 2514848620977022$ journals.sagepub.com/home/ene

@SAGE

\section{Emily Potter $\mathbb{D}$}

Deakin University, Australia

\section{Fiona Miller (D)}

Macquarie University, Australia

\section{Eva Lövbrand}

Linköping University, Sweden

\section{Donna Houston, Jessica McLean and Emily O'Gorman}

Macquarie University, Australia

\section{Clifton Evers}

Newcastle University, UK

\section{Gina Ziervogel}

University of Cape Town, South Africa

\begin{abstract}
In this article, on behalf of The Shadow Places Network, we outline a working manifesto of politics and practice. We mobilise the format of the manifesto to speak to an uncertain and damaged future, to begin to imagine other possible worlds. For feminist philosopher Val Plumwood, whose thinking inspires this network, shadow places are the underside of the capitalist fantasy, 'the multiple disregarded places of economic and ecological support'. In turning towards shadow places, and the unjust and unsustainable processes that produce them, we call
\end{abstract}


for an environmental humanities that reaches beyond abstraction, fosters new responsibilities, considers the uncomfortable, and generates reparative possibilities and alternative futures. We aim to continue to trace out a world of shadow places. We acknowledge that these shadow places cannot be known in full, but through a willingness to engage in careful conversation with the beings and places harmed by (or strategically shielded from) processes of the Anthropocene, we can learn how to relate to each other and these places in more just ways. Recognising that shadow places are impermanent and contingent, this working manifesto does not look to predetermine or prescribe but rather invites conversation, encounter and exchange. In so doing we choose to contribute to making different worlds possible by pursuing new collaborations, new methods and new politics.

\section{Keywords}

Climate change, environmental humanities, co-production, collaboration, manifesto

\section{Introduction}

In this article, on behalf of the Shadow Places Network, we outline a working manifesto of politics and practice to re-imagine and begin to co-produce connections for justice in an era of climate catastrophe. Thinking through the form of the manifesto, and situating our response in relation to other mobilisations of this political genre, we make an offering to an uncertain and damaged future. This is a call to imagine other possible worlds beyond the current crisis brought about by globalised late capitalism, climate change and the ongoing legacy of colonialism. In doing so, we do not shield ourselves from the full glare of environmental catastrophe that is unfolding with an inflated sense of hope, nor extricate ourselves from complicities past and present. We do, however, seek to contribute to making different worlds possible (Osborne, 2018) by pursuing new collaborations, new methods and new politics that 'cry against the irreversibility of damage' (Tsing et al., 2017) and seek to cultivate reparative relations and tactics in a climate-altered future and present.

We (a collective of environmental social science and humanities scholars, artists and activists from Australia, Sweden, South Africa and England) take our inspiration and starting point from the work of Australian feminist philosopher Val Plumwood, whose 2008 article 'Shadow Places and the Politics of Dwelling' inspires the network. Ecojustice concerns permeate much of Plumwood's writings on the origins and implications of the hyper-separation of nature and culture (for example, Plumwood, 1991, 2002a, 2002b, 2005). She challenges us to think about the multiplicity of places unevenly impacted by capitalist domination, our relations with these, with each other and with the more-than-human world in more caring, responsible and ethical ways. She challenges us too, to think and act differently as privileged subjects of western modernity.

An expanded and relational notion of connection to multiple places, people and species (see also McLean et al., 2018; Muir, 2014; O'Gorman, 2014) is particularly needed in the face of climate crisis. The forces and effects of this crisis are simultaneously global and local, connecting places across vast distances through fossil fuel economies, and with devastating consequences for places, people and species, permeating all Earth's life-support systems. This is a particularly toxic and violent geography of contribution, connection and consequence in which subject positions are vastly uneven. Shadow places are capitalism's externality: they are its 'disregarded places of economic and ecological support' (Plumwood, 
2008: 139). This is a geography that is not easy to trace, and yet its neglect or forgetting continues to perpetuate the fantasy of untouched western lives in abstract circuits of production, consumption and disposal. Shadow places bare the marks of these processes; they wear them; they are them.

Plumwood calls on us to also think about the places of life-support as well as the places affected by our toxic and violent consumerist lifestyles. She takes to task ecological forms of consciousness that prioritise a singular, idealised and atomised sense of place. She critiques a myopic focus on relations with particular valued places as contributing to the neglect of the places, people and species implicated in maintaining industrially and structurally produced privilege. A number of the authors of this article reside in Australia, explaining the attention to the experience of and resistance to settler colonialism in Australia. Yet the challenges of decolonisation, justice and ecological repair Australia confronts resonate globally with many other places also transformed by the violence of global capitalism and the climate crisis.

The challenge, then, is to 'make our ecological relationships visible and accountable' (2008), as well as to reveal the imaginaries, ideologies, practices and structures that contribute to the creation of shadow places and the destruction of lifeworlds. This is also to write through and in acknowledgement of our privilege as authors supported by institutions historically steeped in exploitative, exclusionary practices, but also as various versions of 'white' western subjects who have benefited from capitalist-colonialist cultures. While not all authors are Australian, the politics of the settler-colonial state motivates us. We are informed by the Indigenous scholar Ambelin Kwaymullina's (2019) assertion that 'all settlers are privileged in relation to Indigenous peoples because anyone who came here postdispossession benefited, or inherited the benefits of, the dispossession of those who where here before' (122).

This privilege is not only normalised in the structures and discourses of the capitalistcolonial state, it is naturalised through a multiplicity of practices that we deploy, daily. In a scholarly sense, this includes how we write, and how we engage in critical discussion. The collaborative nature of this article is a refusal to elevate the individual over the collective, despite the continued rehearsal of the lone author, or thinker, at the centre of western scholarly culture. Our deliberate effort to situate our work in the context of much work before us is an assertion of the relational nature of knowledge and political action. We thus understand our accountability as plural, along with our communities, and 'ecology' as expansive, taking in relations on a dynamic range of scales. In doing so our engagement with shadow places as 'a different project, and [a] much more politically and environmentally demanding project, than that of cherishing one's own special place of dwelling' (Plumwood, 2008), something that environmental movements in the privileged west have historically focused on - those proximate places to our daily lives and imaginaries. How do we expand these imaginaries of connection, and see entanglements that weave far beyond local geographies, and across lives and communities?

In our manifesto we ask:

What can we do differently, as we confront this reality? How can we think and feel differently, in generative and restorative ways? How do we orient ourselves to shadow places whilst maintaining a light on the practices that construct these harmed places and their beings?

In turning towards shadow places, and the unjust and unsustainable processes that produce them, our emergent network seeks to contribute to an environmental humanities that reaches beyond abstraction, fosters new responsibilities, and considers the uncomfortable. 
As such, we work towards generating reparative possibilities and alternative futures through our scholarship, art and activism.

The article first outlines the appeal and purpose of writing a manifesto, and why as a network we were drawn to this mode of writing. A brief review of the manifesto genre is provided, highlighting contemporary examples of activist and scholarly texts that adopt this form, and in particular those manifestos that also traverse decolonial, social justice and ecological concerns. We point to common modes, themes and demands from these manifestos that resonate with our concerns, and critically appraise some of these and their limitations which have informed our ethos. The article then outlines key themes, authors and ideas that informed the development of our manifesto. We here elaborate why we are in conversation with inside and outside the academy, and within and beyond the geographical contexts we write from, before concluding with the manifesto itself.

\section{The manifesto genre: A response to urgency, a call to action}

In galvanising a shadow places perspective we draw upon our experience as scholars and artists in various cultural contexts, to suggest principles of practice for thinking, feeling and doing things differently in a transforming world. We reassert the value of an explicit politics in our practice. We do not write into a vacuum and our intellectual context is a dynamic field of critical environmental thought. We are particularly indebted to the environmental humanities, which has long explored and modelled different ways of thinking and doing environmental research. Informing us is a strong tradition of engaged politics apparent in the scholarship of some in the environmental humanities, notably in Indigenous and environmental justice scholarship, as well as in radical and feminist geography (Bear et al., 2015; Davis and Todd, 2017; Davis et al., 2019; Gibson-Graham, 1996, 2011; Hernández et al., 2020; Mitchell, 2016; Muecke, 2004; Neimanis et al., 2015; Plumwood, 1991, 2000, 2008; Pulido and De Lara, 2018; Rose, 1996; Rose et al., 2012; Whyte, 2013, 2017).

While the manifesto genre is an explicitly political form, a recent surge in its popularity across scholarly, artistic and activist fora suggests the correlation between the manifesto and key historical junctures of socio-political urgency: the climate crisis that faces us is one of these. What distinguishes a manifesto from other forms of political writing is that it reflects a particular mode of address - it is declarative, it conveys a sense of urgency, and it is a call to action. Authors of manifestos demonstrate a self-conscious awareness of themselves as political agents. According to Buell (2018: no page), '[m]anifestos are supposed to proclaim, define, or contest norms of practice. Peremptory foreclosure is endemic to them' (Buell, 2014: no page). Burke et al. (2016: 519) argue that they insist on immediate attention as a 'polemical and rhetorical format'. The manifesto is more transgressive than other forms of political writing, necessarily splicing different modes of discourse, refuting structural convention and transcending disciplinarity: 'Manifestos need to combine and confuse where the powerful insist there must be borders and control' (Burke et al., 2016: 519).

While the manifesto genre is famously associated with the pre-war avant garde and aesthetic counter-cultural movements (futurism, Dadaism, and surrealism, for instance), it is a genre with a long and diverse history. Laura Winkiel (2006) traces the manifesto to the political declarations of twelfth century Europe (66), while one of the most famous manifestos of all, Marx and Engels' The Communist Manifesto (1848), is an extended economic treatise with strong literary aspects ('A spectre is haunting Europe ...' (1)). Despite this diversity, power plays a central role in the creation and deployment of manifestos. The power to write a manifesto is a part of this, but also the work of manifestos is to speak truth to power in one way or another. Manifestos might challenge hegemonic regimes as 
well as, in a Foucauldian sense, offering counter-discourses that are generative and restorative. Arguably, the most effective manifestos are nurturing and offer a vision that its audience can take on and make their own, not through distinction or elevation, but through commonalities and shared imaginaries that leave room for difference.

Despite the 'man' in manifesto, which has seen the genre critiqued through a feminist framework (for example, the 1967 SCUM Manifesto (Solanas and Ronell, 2004) and India's National Alliance of Women's Organisation (2014) 'Womanifesto'), it has also been critically deployed by a wide range of feminist scholars, including work in cyberfeminism (VNS Matrix, 1991); posthumanist studies (Haraway, 1985); anti-capitalist perspectives from cultural anthropology (Bear et al., 2015); and in global feminist scholarship itself (Arruzza et al., 2019; Weiss and Brueske, 2018). We acknowledge, too, the association between manifestos and violence (see Solanas, author of the SCUM manifesto in 1967) and the dark racialised history of the manifesto genres, embodied in the 1938 Italian "Manifesto of Racial Scientists' which advanced the anti-Semitic rhetoric that was rising across Europe at the time (Gillette, 2010). This is a history still enacted in new versions of extremist discourse: the perpetrators of recent mass shooting events in Norway (2011) and New Zealand (2018) both published manifestos prior to their crimes, while Solnas famously shot high profile artist Andy Warhol in 1987. We acknowledge these histories and political pressure points, and condemn and reject their violence and exclusion. Whilst the intent of manifestos is to seek to become agents of change, it is the context and intent of that change that matters - it matters how manifestos are manifested. As Haraway (2003: 3) wrote of 'The Companion Species Manifesto', it 'is a personal document, a scholarly foray into too many half known territories, a political act of hope in a world on the edge of global war, and a work permanently in progress, in principle'. We mobilise the genre arguing that no literary form can be irrevocably held hostage to ideology.

It is thus unsurprising that the manifesto genre persists and even flourishes now, at this time of extreme environmental pressure and social inequality, reflecting both a growing sense of urgency regarding the trouble we are in, as well as a recognition of the need for our words to cut through, to have greater political effect, and to build coalitions from common ground. Is it because, through their mode of address and necessarily bold tenor, manifestos encourage us to imagine outwards, to postulate and offer new ways to live with the earth, to rework ourselves accordingly (Plumwood in Gibson et al., 2015). Despite the violence that can spin out from, or alongside, a manifesto, they still implicitly offer words as a 'revolutionary tool': they aspire 'to change reality with words' (Yanoshevsky, 2009: 264).

\section{Manifestos for our time}

Acknowledging the long genealogy of the manifesto, and having traced some of its cohering characteristics, we move to engage with what we identify as key manifestos across the scope of our concerns: (i) Indigenous rights and decolonisation; (ii) ecological crisis and anti-capitalism; and (iii) multi-species and an eco-feminist ethics of care. These manifestos - some, broadly conceived; some explicitly from the academy and others speaking outside it

- illustrate the synonymity of this form with political urgency and times of 'profound social and cultural transformation' (Yanoshevsky, 2009: 260). It is this growing sense of urgency, together with a frustration with the limitations and exclusive nature of academic publishing, that has drawn us to the manifesto genre in order to engage in a more expansive public discourse. We also reflect on what our manifesto might contribute to this already dynamic and growing field, and believe that by explicitly bringing these related concerns together our manifesto draws connections not yet articulated. 
(i) Indigenous rights and decolonisation. Climate change and mass extinction are the result of colonial, especially settler colonial, processes, as argued by Davis and Todd (2017), Davis et al. (2019), Haraway (2016), Whyte (2017) and others. Decolonisation is thus central to addressing the shadow places created by climate change. Processes that begin by listening to and engaging with Indigenous concerns and knowledges, and seek to contribute to decolonisation/anti-colonisation, are thus central to any project of justice and repair.

In settler-colonial Australia, where many of the authors reside, Indigenous peoples have repeatedly and clearly articulated their demands asserting Aboriginal and Torres Strait Islander rights, sovereignty and knowledges. This has been through a range of declarative forms analogous with the manifesto, including epistolary activism (William Barak's 'Letter to the Editor by the Coranderrk Aborigines', 1882; Bessie Cameron's 'Letter to the Editor', 1886), petitions (William Cooper's 'Petition to the King', 1933 and the Yirrkala Bark Petition, 1963), and other statements of opposition and intent, such as Anna Morgan's 'Under the Black Flag' (1934) and William Ferguson and John Patten's 'Aborigines Claim Citizen Rights!' (1938; Heiss and Minter, 2014: 15, 16-17, 28, 49-50, 29, 30-31) which demanded a 'New Deal for Aborigines', with a clear call for reckoning and substantive justice: 'You are the New Australians, but we are the Old Australians ... You have almost exterminated our people, but there are enough of us remaining to expose the humbug of your claim, as white Australians, to be a civilised, progressive, kindly and humane nation ... you stand condemned in the eyes of the civilised world' (in Heiss and Minter, 2014: 31). From these earlier declarations to more recent efforts to transform settler colonial Australia (such as the Barunga Statement in 1988, and more contemporary expressions, outlined below), work that resonates with the manifesto has long been a strategy for Indigenous Australians to resist, and attempt to reform, the Australian state.

A clear framework for decolonisation emerges from a number of manifestos in recent years, including those provided by Aboriginal youth (Warriors of Aboriginal Resistance, 2014) and emerging from the National Freedom Movement - see the Sovereign Union's (2015) Aboriginal Sovereign Manifesto of Demands. These manifestos reject the language of recognition and reconciliation that is assimilable to colonial-state logic, instead demanding Aboriginal rights to self-determination, sovereignty, redress and compensation. They offer a radical and hopeful recasting of Indigenous and non-Indigenous relations. More recently, the Uluru Statement from the Heart (2017) reflects the collective hopes and demands of First Nations leaders from across the country, rejecting the mere symbolic recognition of Aboriginal and Torres Strait Islander peoples in the Australian constitution, for more substantive measures towards justice. The Statement calls for a First Nations voice to parliament - a representative body - and a process for a treaty (Makarrata). The statement invites coalition building and appeals to people to "walk with us in a movement of the Australian people for a better future'. Manifestos may not just articulate demands but invite connection, and because of this are not simply rhetorical, but can proceed as a practical affordance for change. Notably, the Statement was presented (like the Yirrkala Bark Petition and the Barunga Statement before it) as an artwork that is also a political document, surrounded by the signatures of all delegates present at the First Nations summit. It was also addressed straight to the Australian people, rather than to parliament and the figureheads of constitutional power. These different modes of presentation and address point to the need to acknowledge manifestos outside conventional written frameworks and modes of political address.

Manifestos have a history amongst other colonised peoples beyond Australia, including the 1969 landmark anti-colonial work, Custer Died for your Sins: An Indian Manifesto by scholar and activist Vine Victor Deloria Jr, which critiques the violence of colonial 
governmentality and advocates sovereignty and self-governance amongst native American tribes. More recently, Professor of American Indian Studies, Melissa K Nelson, produced 'The Future of Native Studies: A Modest Manifesto', as a call to reconsider the value of Native American studies for Native American people, asserting the importance of scholarly practice that is committed to decentring colonial frameworks in a project of activism and change. She situates her manifesto in the context of environmental crisis, and the necessary centrality of Indigenous knowledges to the project of environmental and social justice. Similarly, crisis and a non-linear Indigenous conception of time are central to the powerful and provocative, 'Rethinking the Apocalypse: An Indigenous, Anti-futurist Manifesto'. The authors warn against 'apocalyptic idealization', and in asserting an Indigenous antifuturism, as '[c]apitalists and colonizers will not lead us out of their dead futures' (Indigenous Action, 2020: 4).

Beyond the settler-colonial states such as Australia and the US, the ongoing effects of colonialism are taken up by other authors in a range of contexts and addressed by nonindigenous scholars in the manifesto form. A notable contribution is offered by Kathryn Yusoff (2017) in her piece 'A Minoritarian Manifesto for Reoccupying the Strata'. Here, she critiques the colonial production of knowledge through the discipline of geology, and how this has contributed to the persistent economies of the settler colonial west. In doing so, she provides a new way of thinking and feeling about the production of knowledge - located in how we understand and touch the earth. This is a counterpoint to the spherical, planetary, connective point of view associated with dominant framings of the Anthropocene - a widely contested term (see Davis and Todd, 2017; Houston, 2013a) that has come to designate human dominance of earth systems, signalling a new geologic epoch (Crutzen, 2002). Yusoff goes down (and up), rather than around. She calls for 'reoccupying the geosocial strata' (Yusoff, 2017: 123), to confront the social divisions and modes of power that are enacted through geologic forms and global environmental transformations associated with the Anthropocene, notably extractivism.

There is an 'intrastratum of networked oil rigs and underground horizontal drilling that moves through and across stratifications' (Yusoff, 2017: 108) that are economic, social and cultural. The alignment of socio-economic power with geostrata forces us to see how the geologic is entangled with social stratification. Yusoff explicitly questions the paradigm of 'planetary governance' (119) as reproducing 'surface-level entrepreneurial capitalism" (119) which obscures 'another set of capitalizing relations on the substratum', embedded in the 'mineralogical cycles of the earth' (119). So, Yusoff's Minoritarian Manifesto provides a counter-Anthropocene approach, calling us to: 'Work to recognize the modes of exhaustion (planetary, ecological and social) that characterize those geosocial interventions in the strata' (123). Yusoff's work counters the universalisation logic that undergirds the Anthropocene, arguing that the scientific premise of this epoch attempts to obliterate the power behind geotraumas.

The Minoritarian Manifesto demonstrates the power of manifestos in forcing us to rethink our frames of reference, our ways of imagining and our paradigms of change. Tariq Jazeel (2019) provides a different approach to decolonisation in 'Singularity. A manifesto for incomparable geographies'. His focus is the sometimes unintended violence of comparison in the production of geographic knowledge, and the critical impulse to singularity that must accompany decolonisation. Jazeel calls for a radical engagement with context and the particular. Jazeel acknowledges the manifesto as a 'bombastic' and 'imperfect trope' (6) but one that is still methodologically generative: it is an intervention whose revolutionary zeal can be oriented towards not overthrow or displacement, but transformation - particularly transformation in the 'the shape of ... knowledge' (11). 
The 'Manifesto Athropoceno', a manifesto from the Critical Studies of the Anthropocene research platform at the Pontifical Catholic University in Chile, acknowledges colonialism as one of the primary drivers of the Anthropocene, and seeks redress through a " profound recognition" of Indigenous peoples'. Timothy Neale translates from the manifesto: 'Chilean society has been "hiding its ancestral cultures,"... and this needs to end' (Neale, 2019: 489). As Neale points out, however, this paradigm of recognition as inclusion (for the manifesto's authors "to recognise "our" (nuestros) Indigenous peoples, focusing on how they "embody knowledge and sensibilities" that must be ... incorporated into the wider political community' (489)), is problematic, particularly when put into conversation with the settler-colonial politics emergent from the Australian situation, where the 'cunning of recognition' can actually re-affirm colonial sovereign power and continue to marginalise and disempower Indigenous peoples (Povinelli in Neale, 489).

(ii) Ecological crisis and anti-capitalism. Many recent manifestos explicitly position themselves in reaction to ecological crises. Despite their variant cultural positioning (Dark Mountain, for instance, reflects a western-centric reverence of 'nature' citing almost exclusively from the English and American literary canon, while the Leap Manifesto foregrounds social justice and equity as central to environmental well-being), there is a shared attention to the value of storytelling. This echoes the manifesto's performative and poetic modality (Hanna, 2014), as well as the tension between resistance and reform in the urgency of the current situation.

The Uncivilisation: The Dark Mountain Manifesto (Kingsnorth and Hine, 2009) is one of the earlier manifestos to address the current 'ecocide'. It is written in a popular voice and, although ultimately retreating to an apolitical stance ("We reject the faith which holds that the converging crises of our times can be reduced to a set of "problems" in need of technological or political "solutions" (no page)), the manifesto nonetheless rhetorically asserts the significance of stories and storytelling in contributing to the current crisis. Writing that 'the roots of these [ecological] crises lie in the stories we have been telling ourselves. We intend to challenge the stories which underpin our civilisation: the myth of progress, the myth of human centrality, and the myth of our separation from "nature". These myths are more dangerous for the fact that we have forgotten they are myths' (Kingsnorth and Hine, 2009: no page). They call for world-making that seeks to 'reassert the role of storytelling as more than mere entertainment' (Kingsnorth and Hine, 2009: no page) reminding us that '[i]t is through stories that we weave reality' (Kingsnorth and Hine, 2009: no page). Stories are deeply political, on an imaginary level, yet also they have potential to contribute to political mobilisation, if this is indeed their intent.

Manifestos that focus more clearly on political mobilisation and socio-political and economic transformation are also responding to the urgency and magnitude of the ecological crisis we live (and produce). Published in Canada, but linked with the 'degrowth' movement of Europe (see D'Alisa et al., 2014), the Leap Manifesto embraces the need for political storytelling. It brings together social, climate and environmental justice concerns through its focus on 'the intersecting crises of climate change, inequality, and racism' (Leap, 2015: no page). The Leap Manifesto starts with a recognition of the need to respect the rights of Indigenous peoples. The broad based coalition of interests and individuals behind the manifesto seek to bring about systemic change through 'bold storytelling and public interventions; local organizing around climate and social justice solutions; and silo-busting movement gatherings' (Leap, 2015: no page). It is not just about critique and rejection, but also coming up with clear alternatives and ways to fund them, with Indigenous and social justice placed at the heart of environmental action (Leap, 2015). Similar demands to halt fossil fuel industry subsidies and to create green jobs, invest in green infrastructure and 
ecologically restorative projects, are taken up in the proposed Green New Deal promoted by (some) Democrats in the US (Ocasio-Cortez, 2019). Here, the manifesto acts to not just reject but to help re-imagine alternatives to our current destructive cultures of extraction and consumption, and to translate these provocative ideas into deliberative, democratic action.

In contrast, the manifesto of the rapidly growing Extinction Rebellion is less about detailed alternatives and more about disruption. It follows a broadly defined set of principles of non-violent protest and popular mobilisation and has a (brief) manifesto. It has just three demands: declare the climate and ecological/extinction emergency; halt biodiversity loss and push for net zero greenhouse gas emissions by 2025; and create citizen-led assemblies to achieve climate and ecological justice (Extinction Rebellion, 2018). These three demands distil and somehow unify many disparate concerns from across the climate justice movement. Their form of protest (often resulting in mass arrests), however, is not accessible to all people, such as migrants, the poor, First Nations peoples and people of colour who are already subject to the racialised violence of states and to disproportionately higher rates of incarceration than privileged (white) majorities, as so painfully revealed in the Black Lives Matters protests of 2020. As such, a political movement that reinforces rather than dismantles privilege in its way of mobilising is not one that is truly inclusive.

In 1996, the Zapatista Army of National Liberation, or Ejército Zapatista de Liberación Nacional (EZLN), presented their political and activist principles and vision for Mexico and beyond. Their declaration calls for 'walking with' (as also in the Uluru Statement from the Heart) the Zapatistas to engage in activism and struggle for democracy and justice against neoliberalism (Sundberg, 2014). The 'walking with' refers to mutual respect among those involved in the struggle as there is a multiplicity of world(s) at stake - a pluriverse (Sundberg, 2014). The Zapatismo movement has inspired, taught, and transformed many activists and organizations, including those intent on decolonizing knowledge and activism (Sundberg, 2014). Their multi-decade struggle has involved many different forms of activism and ways of organising, including digital media. The Zapatista became a widely cited example of how digital media can aid activism in achieving transnational activist networks and organize worldwide global counter publics (Hands, 2011). While technological affordances are inevitably mitigated by already formed understandings of democracy or other political persuasion (Dahlberg, 2011), politics has nevertheless been refigured partially due to digital media where a wider range of people play an active role as content producers to collectivise and participate. We advocate this when it works as a non-hierarchical democracy and goes beyond paradigms of celebrity, privilege, domination and exploitation to one of radical ethical and connected world(s)-building that champions 'collaborating, cooperating, distributing, exchanging, giving, networking, participating, [and] sharing' (Dahlberg, 2011: 865).

(iii) Multi-species and an eco-feminist ethics of care. Donna Haraway gave great momentum to animal studies and more-than-human theory with the publication of The Companion Species Manifesto: Dogs, People, and Significant Otherness in 2003. As with her earlier manifesto, $A$ Cyborg Manifesto, first published in 1985, Haraway continued to problematise the natureculture dualism. Since these, there have been a number of influential manifestos seeking to progress multi-species thinking and ethical relations of care and connection.

For Collard et al. (2015) their A Manifesto for Abundant Futures (or 'Another a Path is Possible! Abundant Futures Manifesto') seeks to chart 'An alternative path for multispecies abundance', where abundance is understood to mean 'diverse and autonomous forms and ways of living together' (Collard et al., 2015: 322). The manifesto declares decolonisation as the authors' driving political motivation, as well as the influence of global Indigenous 
movements on their vision for enacting multispecies worlds. Their Manifesto comprises three 'Strategies': Reckoning with Colonial-Capitalist Ruination; Acting Pluriversally; and Recognizing Animal Autonomy. They declare: 'We choose the manifesto as a declarative format that makes a path-changing proposal "to stop going further in the same way as before toward the future"" (Collard et al., 2015: 323).

For three feminist scholars, Gibson et al. (2015), methodologies of connection and interdependence inform their Manifesto for Living in the Anthropocene. 'Separation (or binary) thinking denies our co-produced realities' (Gibson et al., 2015: 17), they contend. Gibson et al.'s manifesto carries a declaration of pain and sorrow ('the tragedy of anthropogenic climate change' (vii)), but this is mobilised through the experimental format of the text as a disposition, or embodied stance, that might motivate new, critical insights. They wonder: "Might it be possible to welcome the pain of "knowing" if it led to different ways of working with non-human others, recognizing a confluence of desire across the human/non-human divide and the vital rhythms that animate the world' (Gibson et al., 2015: vii). These different ways of working are explored through reflective engagements with diverse placebased methodologies, including listening (Gallagher et al., 2017; Kato, 2015), walking (Instone, 2016), deep mapping (Somerville, 2016), 'speculative ethology' (Garlick, 2019) and dialogue (Rose, 2016). These practices accord with other methodological modes from cultural studies and related fields, such as wet ethnography (Evers, 2015; Probyn, 2016), and Indigenous Hawaiian scholar Karin Ingersoll's (2016) emphasis on oceanic relations as an epistemological starting point.

The Care Collective's (forthcoming) The Care Manifesto calls for a rethinking of care at a time of care's crisis, across human and non-human communities. With particular resonance in an age of COVID-19, this manifesto unpacks the violence of privatisation and deregulation that have devalued care in neoliberal societies, and are now confronted by the failure of the myth of 'economic growth' to underscore a good, healthy life. The Care Manifesto offers a radical rethinking of care paradigms that puts relationality, egalitarianism and democracy at its heart. Its vision of 'caring politics' is founded on the principles of: interdependence; caring kinships; caring communities; caring states; caring economies; and caring for the world, as also expressed by the Creatures Collective (Hernández et al., 2020) and Davis et al. (2019).

From the study of International Relations (IR), Burke et al. (2016: 499-502) put forward a 'multi-species, multi-disciplinary action plan' (502) that prioritises 'forming alliances and fostering interdisciplinarity' (499) across areas of expertise - a call for a new 'political imagination' (500). In their Manifesto from the End of IR, they advocate 'planet politics' as an alternative thought and process to 'nurture worlds for all humans and species co-living in the biosphere' (Burke et al., 2016: 500). To confront a state-centric world obsessed with bargaining, power and interest, they declare the need to: 'Transgress academic boundaries to create conversations with activist networks and movements engaged in struggle against oppressive regimes and systems' (Burke et al., 2016: 501). In a time when human societies are dangerously enmeshed with the biosphere, 'security comes from being more connected, not less' (502). Planet politics here becomes a call for relevant disciplines to:

Support, enable and clarify this new politics of just ecological entanglement and mutual survival. A complex politics of musts: End extinctions! Preserve biodiversity! End deforestation! Repair the oceans! Prevent climate disaster! Decarbonise humanity! Return to social justice! Animals of the world, unite! (522)

Yet even while the manifesto can be subject to inconsistencies and imperfection, it's capacity for disruption is a constant. Latour points out that even while the manifesto is a 
modernist favourite, with a legacy of human-centric temporality (i.e., its association with change and 'moving forward'), the manifesto can radically transform definitions of progress. This is the manifesto '[n]ot as a war cry ... but rather as a warning, a call to attention, so as to stop going further in the same way as before'. This is a process of 'composting', of churning through and remaking common worlds from what has been undone (Latour, 2010: 473), but also from what has been done before (Hamilton and Neimanis, 2018) - something that also makes us attentive to what Sarah Ahmed (2013) terms 'the politics of citation' that informs our manifesto's composition.

\section{Positioning A Manifesto for Shadow Places}

Despite their differing origins, inflections and orientations, the multiplicity of manifestos that we have reviewed resonate with our own motivations in response to the climate crisis. However, there are particular aspects that we find in solidarity, and that cohere across many of these approaches. These are: a prioritisation of decolonisation, and the decentring of white, masculine, capitalist, colonial power from global to intimate power structures, as well as social, cultural and economic imaginaries; multispecies justice and rights; and an acknowledgment of multiplicity, pluriversality and entanglement as a condition of being and knowing. In this reorientation away from dominant, destructive western paradigms of living in the world, questions of responsibility take centre stage, possibilities for reckoning and repair open up, and an ethical relationality comes to the fore. As Indigenous American scholar Dwayne Donald (2009) explains:

Ethical relationality is an ecological understanding of human relationality that does not deny difference, but rather seeks to more deeply understand how our different histories and experiences position us in relation to each other. This form of relationality is ethical because it does not overlook or invizibilize the particular historical, cultural, and social contexts from which a particular person understands and experiences living in the world. It puts these considerations at the forefront of engagements across frontiers of difference. (6)

Such possibilities are never set or determined, of course, but involve ongoing variation. Our manifesto cannot determine what might be capable or possible nor does it intend to confirm what we already know. Instead, it amplifies and seeks out relationality, creativity and hope. In taking its inspiration from Plumwood's philosophy, we acknowledge that we are spotlighting a non-indigenous scholar in our efforts to contribute to a decolonising ambition. However, our situated politics demand that we interrogate western white privilege from the inside, looking, too, to dissonant traditions within the non-indigenous political imaginary. In this way, we do not call on Indigenous thinkers to provide all the solutions: we undertake the allied work of dethroning our conceptual traditions, cracking open received systems of knowledge and power, to 'yield' critical and political space to others. Val Plumwood as a thinker and activist modelled a feminist ethics of relationality, and while we cite her name, we also acknowledge, as she did herself, the more-than-human material and intellectual networks that gave shape to her politics and practice. 'Plumwood', as Zoë Coombe reminds us, is a native eucalypt (Eucryphia moorei) after which Plumwood chose to name herself, that germinates as it attaches to an already established native fern. Instead of ultimately sapping the fern, these two plants grow together, 'taking on a form shaped by the ongoing negotiations of their intertwined existences' (Coombe, 2020). Putting this kind of relation at the centre of a manifesto is an attempt to restate declarative politics as dependent upon ongoing inter-dependence, rather than a fantasy of rupture and remaking. We speak 
from a self-aware position of both scholars and political subjects in the world, who occupy positions of institutional, economic and cultural privilege, and who write within this context. However, we also consciously face outwards, beyond scholarly boundaries: amongst our network are artists and activists, and our focus is on ideas as they materially manifest and have impacts in the world. Ours is a project informed by imperative to move scholarly practice into hybrid and collaborative forums, where potential audiences open up. The manifesto form is one attempt to do so: it was first published on our website, promoted via social media networks, and is a living text, open for use, contest and debate. It escapes the paywall structures of scholarly publishing and directly addresses an expanded public of concern through its language and structure.

\section{Decolonial intent and engagement with Indigenous knowledges}

Our decolonial intent is not emergent from a blue water theory of colonialism but rather it resonates globally, beyond Australia as a settler-colonial product of empire. Colonial exploitation has shaped the world through the spread of global capitalism and climate change. We have people writing from empire (Potter, Miller, Houston, Evers, McLean, O'Gorman, Ziervogel), and complicit in it, but also outside it (Lövbrand) - although Sweden has its own histories of internal colonisation (Lawrence, 2014). We also acknowledge that the academy is a privileged place that feeds into these histories. It is also caught up in colonial, exploitative and exclusionist cultures. With this in mind, our Manifesto enacts new forms of knowledge production by opening possibilities for generative conversations outside, as well as within, the academy. This resonates with the aims of decolonial scholarship as expressed by Asher, quoted in Jazeel (2019: 835), who argues 'What decolonial scholarship proposes in response to coloniality is a project of delinking knowledge production from the academy rather than scholarly transformation within the academy.' Whilst both projects are important, our Manifesto specifically addresses the project of delinking.

A decolonising manifesto must acknowledge the multiplicity of declarative modes - not just the written form, and encourage other modes of expression, such as the oral and visual to enter conversation with ours. Relatedly, we are guided by the principle that a manifesto has to be open and comprehensible. We question the political purchase of work that alienates through its complexity and exclusivity. While we acknowledge the history of the manifesto as a genre with complex genealogies, sometimes mobilised for authoritarian, hegemonic, patriarchal and violent purpose, we also understand genres as inherently flexible and open to constant challenge and remaking. As we have discussed above, it is not white, masculine hegemons alone who have deployed the manifesto; it has a long history of being effectively deployed for radical purposes in politics (Marx and Engels, 1848) and art (see the Guerilla Girls, n.d.). As such, with the declaration of a manifesto, a conversation can begin rather than end.

Recognising that overreach is what got us here today, we do not want to re-perform this. It is a paradoxical form in that way. Can you be bold enough to call for change, without being strident and imperial? We hope, yes. As such, there are embodied vulnerabilities in declarative intent and the desire to re-compose just and sustainable worlds through collaborative forms of writing/doing/knowing. Thus, we proceed, keeping sight of this tension, and to this extent, what we offer is a modest intervention that is politically hopeful without claiming authority, exclusive insight, emotional detachment or objective distance: we work to create worlds rather than define them. It is a championing of vulnerability and hopefulness, and we locate this hope, in part, in solidarity. The environmental crises we are tracing are being challenged by children, those future generations of decision-makers who are 
leading Climate Strikes around the world (Rose, 2019), organised by digital technologies and mobilising on the streets globally. Rather than being crippled by fear of dangerous climate change, children are saying that we must change (Taylor, 2019).

\section{Urgency of ecojustice concerns}

This manifesto, while informed by various national contexts, coalesces around common ecojustice concerns. For the lead authors, however, some distinct positioning as white settler-colonial subjects is crucial: Australia is currently a significant emitter of greenhouse gases per head of population, and is slated to be an 'emissions superpower' by 2030, contributing a projected $30 \%$ of the global coal trade (Morton, 2019). This reflects a profound and genocidal investment in extractivist socio-economic organisation. Australia's current Prime Minister famously brought a lump of coal into parliament and raised it triumphantly, declaring: 'this is coal! Don't be afraid! Don't be scared!' (Murphy, 2017). But we need to be scared, we must be afraid. The brutal colonisation of Australia decimated Indigenous populations, destroyed ecosystems, and set up the terms of an ongoing, hostile denial of Indigenous sovereignty and the agency of non-human environments. The results today are a stratified society, with profound disadvantage for many, especially Indigenous communities, future generations, growing species extinction, devastation to riverine environments, frequent catastrophic fires and ongoing vegetation clearance and deforestation. At the heart of this is an ideological commitment to human dominion and settler-colonial ascendency, as well as to the ongoing moral purpose of resource extraction and exploitation. After all, what was the colonial project for if it was not to put land and natural resources 'to use' - to maximise profit on the fantasy of terra nullius; a land empty and waiting.

The Anthropocene is now (Davis and Todd, 2017; Graham et al., 2009). It is not a future to come. As we face a cascade of unravelling relationships that have been formed across millennia, on an epic scale globally, the specificity of the Australian situation - a blinkered, arrogant and fearful commitment to the status quo, a strong colonial mentality still, an island consciousness that has fostered disconnection from neighbours rather than connection and the interlinking of our founding narratives with extractivist practices - resonates with the particularly planetary scale of the mess we are in. Plumwood spoke to and out of the Australian situation, and she knew that the Anthropocene and the settler-colonial condition are profoundly connected. Australia is now distinguished as a 'laggard' in the global polity (SBS News, 2017), continuing, even rhetorically ramping-up, its commitment to fossil fuel extraction and burning, even as efforts to decarbonise strengthen across the globe. As such, Australia quintessentially reflects the conditions of the Anthropocene. Hence, the urgency of the political project of ecojustice we signal with our Manifesto for shadow places in Australia and elsewhere.

\section{Methodologies of relationality}

Ecological justice is more-than-human. To come to grips with the relationality of place, beings and ethical transformation, we celebrate methodologies that not only accommodate how humans and nonhumans co-create knowledge but foster such inter and intra-activity. According to Richard Grusin (2015), we can think of the nonhuman as 'animals, plants, organisms, climatic systems, technologies, or ecosystems' (x). Our justice endeavour equates to thinking and feeling with other sentient beings, plants, rocks and water. This methodological orientation involves registering the non-living as vibrant, as mattering and as sharing in meaning-making (Barad, 2007; Bennett, 2010). Knowledge forms travel 
through and across in/non/human bodies displacing boundaries of embodiment and place as it does so. A process ontology is present. While the ontological and epistemological starting points may appear new to some, Indigenous peoples and their scholars, storytellers, teachers and activists have for a long time been proceeding from 'more-than-human' ontologies and epistemologies open to how all objects and beings express vitality and are part of potential (Jones and Hoskins, 2016; Sundberg, 2014; Todd, 2016; Wright et al., 2012). The relationality and complexity means that knowledge is always going to be partial and situated. While we move away from anthropocentrism, this does not mean we do not continue to attend to the enduring production of human subjectivities that proceeds by way of 'intersectional' (e.g. race, sex, gender, species, class) oppressions and unjust ecological realities (Crenshaw, 1989; Davis et al., 2019). Conversations about listening, voice and power are essential. We prioritize experimental and creative methods to affirm, represent and further generate life as transversal, processual and relational. There are multiple, at times indeterminate, and entangled actors.

As environmental feminists have long argued, we need more than science to achieve environmental justice, curiosity and care (Neimanis et al., 2015). We need 'adventures in living' (Gibson-Graham, 2011: 4) and these adventures need to be transdisciplinary as well as achieve public engagement (Neimanis et al., 2015). Methods employed to not only identify but multiply relations and potential work best when they are communal and collaborative. Creative experiments, walking and swimming methods (Evers, 2015), sensory ethnographies, play, performance, poetry and photography can be braided together to assist stories of the world to unfold and connect so as to change course and for some of us to learn how to nurture more ethical and justice-driven worlds to grow. It is, of course, going to be a methodology of uncertainty, trepidation and self-doubt as we do not know what will grow or come to be. But that is OK, if we invest love and hope fresh insights will at least have the opportunity to emerge.

We seek to foster ethical relationality with people, place and non-humans through methods such as stories collaboratively generated through emplaced practice (Potter and Magner, 2018), storytelling in our research and teaching (Houston, 2013b), walkshops (Various, 2019) and artist-academic collaborations. Arts-based methods in particular are crucial to relationality as they can facilitate a wide range of creative participation from people when it comes to knowledge-formation, social transformation and achieving social justice (Foster, 2016; Leavy, 2015; Liamputtong and Rumbold, 2008; van der Vaart et al., 2018). Arts-based methods simultaneously evidence the diffraction of meaning-making through the material world, involving, as it does, the agency of the material world when it comes to any transformation or knowledge-formation (Hickey-Moody, 2020). Arts-based methods can achieve the same when it brings together humans and nonhumans to achieve environmental justice (Sze, 2015).

Our Manifesto is premised on a recognition that political, economic and imaginative structures in certain places contribute to harm elsewhere as well as expressing our shared vulnerabilities. As such, planetary work that is not emplaced generally lacks relations of accountability, reciprocity and responsibility. This approach, untethered from relations to place and people, contributed to Empire, colonisation and global capitalism that got us to this point. As such, the Anthropocene requires us to work, think and imagine differently. You can't do planetary work without place as once you work with communities and place you are embedded in ethical relations of reciprocity, care and responsibility. As such, place is a methodological constant and is a way of doing Anthropocene work differently. 


\section{A Manifesto for Shadow Places}

A manifesto for shadow places is a manifesto of politics and practice. It speaks from a recognition of complicity, from the inhabited situation that we, the authors, occupy as humans, thinkers and makers, privileged in voice and resources. This is a fragile position, consuming much, excluding many. It is a situation that does damage and profits from exploitation. This situation can not persist. Beyond this complicity, we seek to resist. Other worlds are possible, not always in sight and felt. ${ }^{1}$

We are not critical observers. We cast shadows ourselves, yet we are not silent witnesses. This manifesto is a self-reflexive statement of intention, a call to respond and an invitation to listen and act.

It may be an outmoded format, as Latour ironically declared, but we mobilise this here - an anachronism that speaks to the future - because time is far from straightforward; it is running out but this is not predetermined (Head, 2016). We are not, as we have been told, on a path to progress. Instead, much is being undone. Much is being lost and displaced. Ecologies are in crisis. Connections are being severed. Inequities stratify our social worlds.

What can we do differently, as we confront this reality? How can we think and feel differently, in generative and restorative ways? How do we orient ourselves to shadow places whilst maintaining a light on the practices that construct these harmed places and their beings?

For the feminist philosopher Val Plumwood, whose thinking inspires this network, shadow places are the underside of the capitalist fantasy, 'the multiple disregarded places of economic and ecological support' (2007: 139). These places, far from view and mind and sometimes out of sight but up close, are what, she says, we need to face and own, recognise and remember. These places are not outside ourselves, but implicated in the very constitution of our embodied, habitual and social lives. We differentially benefit from these places. We need to love these places, too, not just where we are familiar, Plumwood says.

However, we also acknowledge that shadows are sometimes strategic. There is a politics to shadow that is not simply resolved by illuminating what has been previously forgotten, remembering what has been damaged or lost. Being in the light does not mean anything will necessarily change for the better. At the same time, while much suffers in the shadows, some things thrive, as they are hidden from the gaze and protected from encounters. Shadows can sometimes protect and secure places that might not benefit from close inspection (McLean et al., 2018).

How can we respond to Plumwood's exhortation while acknowledging this complexity? A first step is to ensure our understandings of shadow places are never prescriptive and recognise that they are always partial and situated. Our aim is to modestly advance our thinking and feeling, collaboratively, collectively, discursively, and to continue to trace out a world of shadow places. These shadow places cannot be known in full but through a willingness to engage in careful conversation with the beings and places harmed (or strategically shielded from) historical and contemporary processes of the Anthropocene we can learn how to relate to each other and these places in more just ways. 
Because of this, illumination means something different to revelation. 'Illumination' here is not meant to rehearse the epistemic violence inherent in colonial methods of exploration, extraction and discovery. This is not a project of salvage and preservation. Rather we seek situated and ethical encounters with more-than-humans, people and places. To grow together.

A working manifesto is an ongoing project that inspires but also invites ongoing making.

Shadow places compel us to think about what escapes our notice, what is hidden, severed, suppressed, in the margins and what lies beneath our feet and escapes our perception. Yet, at the same time, what we actually perceive is what we no longer acknowledge.

Shadow places call for the recognition of situated knowledges and multispecies assemblages and relationships between land, bodies, air, and water.

Shadow places invoke our responsibilities to pay attention to historical injustices, power and privilege, environmental destruction and their ongoing stratified socio-ecological effects.

Shadow places call for methods and approaches that engage with a participatory and storied sense (and senses) of place and places.

Shadow places lead us to principles for practice based on an ethics of care and responsibility, an orientation to engagement rather than exploration, relations of consent and accountability, a politics of listening and collaboration rather than isolation or elevation.

Shadow places reveal the injustice of structural forms of violence, erasure and dispossession, and thus a politics of justice - procedural, distributive and recognition.

Shadow places are impermanent and contingent, and so this manifesto does not look to predetermine or prescribe but rather invites conversation, encounter and exchange. It seeks to mobilise, and offer a provocation to think, act, feel and work with connection and the impetus to deploy new and different practices of living and making. With this goal, we advance the following practices for encountering, co-producing and re-imagining connections between places and beings in a time of severe and uneven environmental and social stress:

Collaborative enquiry - transnational, cross-cultural, cross-disciplinary, and more-than-human;

Commitment to multispecies justice, openness, diversity, generosity and welcoming as a practice, as well as an ethos;

Recognition of previous efforts, energy and innovations in this space - an understanding of the prior and future scholarly, artistic and everyday communities and their labours that our work feeds from and towards.

As we turn towards shadow places, and the unjust and unsustainable processes that produce them, we call for an environmental humanities that reaches beyond abstraction, fosters new responsibilities, spends time with what makes us feel uncomfortable, and in turn, generates reparative possibilities and their alternative futures. 
'To know the world that progress has left to us, we must track shifting patches of ruination' (Anna Tsing, 2015: 19)

\section{Highlights}

- A critical review of the manifesto genre and its affordances for environmental humanities and activism.

- A survey of related manifestos and offering of our own Collaborative practice as responsive methodology to the Anthropocene, the imperatives of decolonisation and multispecies justice.

\section{Acknowledgements}

We would like to express our thanks to Dr Karen Le Rossignol of the School of Communication and Creative Arts at Deakin University who helpfully shared some key manifesto references. Finally, we would like to acknowledge that much of this article was written on unceded Aboriginal lands of the Darug, Gadigal and Guring-gai peoples of the greater Sydney region and the Wurundjeri and Boon Wurrung peoples of the greater Melbourne region.

\section{Declaration of conflicting interests}

The author(s) declared no potential conflicts of interest with respect to the research, authorship, and/ or publication of this article.

\section{Funding}

The author(s) disclosed receipt of the following financial support for the research, authorship, and/or publication of this article: We would like to gratefully acknowledge funding for The Shadow Places Network made possible by a grant from The Seed Box - A Mistra-Formas Environmental Humanities Collaboratory (Sweden).

\section{ORCID iDs}

Emily Potter (D) https://orcid.org/0000-0002-4171-3002

Fiona Miller (D) https://orcid.org/0000-0003-4427-6466

\section{Note}

1. The Manifesto was first published at https://www.shadowplaces.net/manifesto in March 2019.

\section{References}

Ahmed S (2013) Making feminist points' Feminist Kill Joys. Available at: https://feministkilljoys.com/ 2013/09/11/making-feminist-points/ (accessed 11 September 2019).

Arruzza C, Bhattacharya T and Fraser N (2019) Feminism for the 99\%. London: Verso.

Barad K (2007) Meeting the Universe Halfway: Quantum Physics and the Entanglement of Matter and Meaning. Durham, NC: Duke University Press.

Bear L, Ho K, Tsing A, et al. (2015) Gens: A Feminist Manifesto for the Study of Capitalism. Theorizing the Contemporary, Fieldsights, Cultural Anthropology Online, March 30. Available at: https://culanth.org/fieldsights/gens-a-feminist-manifesto-for-the-study-of-capitalism (accessed 22 November 2020).

Bennett J (2010) Vibrant Matter: A Political Ecology of Things. Durham, NC: Duke University Press. 
Buell L (2014) Manifesto as interrogation. Resilience: A Journal of the Environmental Humanities 1(1), Available at: www.jstor.org/stable/10.5250/resilience.1.1.05 (accessed 22 November 2020).

Burke A, Fishel S, Mitchell A, et al. (2016) Planet politics: A manifesto from the end of IR. Millennium 44(3): 499-523.

Care Collective (forthcoming) The Care Manifesto. London: Verso Books.

Collard RC, Dempsey J and Sundberg J (2015) A manifesto for abundant futures. Annals of the Association of American Geographers 105(2): 322-330.

Coombe Z (2020) Plumwood. An A-Z of Shadow Places Concepts, The Shadow Places Network, Available at: https://www.shadowplaces.net/concepts (accessed 29 October 2020).

Crenshaw K (1989) Demarginalizing the intersection of race and sex: A black feminist critique of antidiscrimination doctrine, feminist theory and antiracist politics. University of Chicago Legal Forum 140: 139-167.

Crutzen P (2002) Geology of mankind. Nature 415(3 Jan): 23.

Dahlberg L (2011) Re-constructing digital democracy: An outline of four 'positions'. New Media \& Society 13(6): 855-872.

D'Alisa G, Demaria F and Kallis G (2014) Degrowth: A Vocabulary for a New Era. Abingdon: Routledge.

Davis $\mathrm{H}$ and Todd Z (2017) On the importance of a date, or decolonizing the Anthropocene. ACME: An International E-Journal for Critical Geographies 16(4): 761-780.

Davis J, Moulton A, Sant L, et al. (2019) Anthropocene, Capitalocene, ... Plantationocene?: A manifesto for ecological justice in an age of global crises. Geography Compass 13: 1-15. https://doi.org/ $10.1111 / \mathrm{gec} 3.12438$

Donald D (2009) Forts, curriculum, and Indigenous Metissage: Imagining decolonization of Aboriginal-Canadian relations in educational contexts. First Nations Perspectives 2(1): 1-24.

Evers C (2015) Researching action sport with a GoPro ${ }^{\mathrm{TM}}$ camera: An embodied and emotional mobile video tale of the sea, masculinity and men-who-surf. In: Researching Embodied Sport. London: Routledge, pp. 145-162.

Extinction Rebellion (2018) Extinction rebellion: Our demands. Available at: https://rebellion.earth/th e-truth/demands/ (accessed 8 August 2019).

Foster V (2016) Collaborative Arts-Based Research for Social Justice. Oxon: Routledge.

Gallagher M, Kanngieser A and Prior J (2017) Listening geographies: Landscape, affect and geotechnologies. Progress in Human Geography 41(5): 618-637.

Garlick B (2019) Cultural geographies of extinction: Animal culture among Scottish ospreys. Transactions of the Institute of British Geographers 44: 226-241.

Gibson-Graham J-K (1996) The End of Capitalism (As We Knew It): A Feminist Critique of Political Economy. Oxford: Blackwell.

Gibson-Graham J-K (2011) A feminist project of belonging for the Anthropocene. Gender, Place and Culture 18(01): 1-21.

Gibson K, Rose DB and Fincher R (2015) Manifesto for Living in the Anthropocene. Santa Barbara, CA: punctum books.

Gillette A (2010) The origins of the 'Manifesto of racial scientists'. Journal of Modern Italian Studies 6(3): 305-323.

Graham J, Gibson K and Roelvink G (2009) An economic ethics for the anthropocene. Antipode 41(1): 320-346.

Grusin R (ed.) (2015) Introduction. In: The Nonhuman Turn. Minneapolis: University of Minnesota Press, pp. i-xiii.

Guerilla Girls (n.d.) Guerilla Girls Activist Work. Available at: https://www.guerrillagirls.com/ (accessed 20 June 2019).

Hamilton J and Neimanis A (2018) Composting feminisms and environmental humanities. Environmental Humanities 10(2): 501-527.

Hands J (2011)@is for Activism: Dissent, Resistance and Rebellion in a Digital Culture. London: Pluto Books. 
Hanna J (2014) Manifestos: A Manifesto. The Atlantic, 24 June. Available at: https://www.theatlantic. com/entertainment/archive/2014/06/manifestos-a-manifesto-the-10-things-all-manifestos-need/ 372135/ (accessed 8 August 2019).

Haraway D (1985) Manifesto for cyborgs: Science, technology, and socialist feminism in the 1980s. Socialist Review 80: 65-108.

Haraway DJ (2003) The companion species manifesto: Dogs, people, and significant otherness. Vol. 1. Chicago, IL: Prickly Paradigm Press, pp. 3-17.

Haraway D (2016) Making kin: Anthropocene, Capitalocene, Plantationocene, Chthulucene. In: Staying with the Trouble: Making Kin in the Chthulucene. Durham, NC: Duke University Press, pp. $99-103$.

Head L (2016) Hope and Grief in the Anthropocene. London: Routledge.

Heiss A and Minter P (2014) Macquarie PEN Anthology of Aboriginal Literature. Crows Nest: Allen \& Unwin.

Hernández KJ, Rubis JM, Theriault N, et al. (2020) The creatures collective: Manifestings. Environment and Planning E: Nature and Space. Epub ahead of print 2020. DOI: 10.1177/ 2514848620938316

Houston D (2013a) Crisis is where we live: Environmental justice for the Anthropocene. Globalizations 10(3): 439-450.

Houston D (2013b) Environmental justice storytelling: Angels and isotopes at Yucca Mountain, Nevada. Antipode 45(2): 417-435.

Hickey-Moody A (2020) New materialism, ethnography, and socially-engaged practice: Space-time folds and the agency of matter. Qualitative Inquiry 26(7): 724-732.

Indigenous Action (2020) Rethinking the apocalypse: An Indigenous anti-futurist Manifesto. Available at: http://www.indigenousaction.org/rethinking-the-apocalypse-an-indigenous-anti-futur ist-manifesto/ (accessed 17 July 2020).

Ingersoll KA (2016) Waves of Knowing: A Seascape Epistemology. Durham, NC: Duke University Press.

Instone L (2016) Walking as respectful wayfinding in an uncertain age. In: Gibson K, Rose DB and Fincher R (eds.) Manifesto for Living in the Anthropocene. Santa Barbara, CA: Punctum Books, pp.133-138.

Jazeel T (2019) Singularity. A manifesto for incomparable geographies. Singapore Journal of Tropical Geography 40(1): 5-21.

Jones A and Hoskins T (2016) Critical Conversations in Kaupapa Maori. Wellington: Huia Publishers.

Jones A and Hoskins TK (2016) A mark on paper: The matter of indigenous-settler history. In: Posthuman Research Practices in Education. Dordrecht: Springer, pp. 75-92.

Kato K (2015) Listening: Research as an act of mindfulness. In: Gibson K, Rose DB and Fincher R (eds.) Manifesto for Living in the Anthropocene. Santa Barbara, CA: Punctum Books. pp. 111-116.

Kingsnorth and Hine (2009) The Dark Mountain Project. The uncivilisation: The Dark mountain Manifesto. Available at: https://dark-mountain.net/about/manifesto/ (accessed 8 August 2019).

Kwaymullina A (2019) Respect, relationships, renewal: Aboriginal perspectives on the worlds of tomorrow. Westerly 64(1): 120-135.

Latour B (2010) An attempt at a "compositionist manifesto". New Literary History 41(3): 471-490.

Lawrence R (2014) Internal colonisation and Indigenous resource sovereignty: Wind power developments on traditional Saami lands. Environment and Planning D: Society and Space 32(6): 1036-1053

Leap (2015) The leap Manifesto. Available at: https://eapmanifesto.org/en/the-leap-manifesto/ (accessed 8 August 2019).

Leavy P (2015) Method Meets Art: Arts-Based Research Practice. 2nd ed. New York, NY: The Guilford Press.

Liamputtong P and Rumbold J (2008) Knowing Differently: Arts-Based and Collaborative Research Methods. New York, NY: Nova Publishers.

McLean J, Lonsdale A, Hammersley L, et al. (2018) Shadow waters: Making Australian water cultures visible. Transactions of the Institute of British Geographers 43(4): 615-629. 
Marx K and Engels F (1848) The Communist Manifesto in Marx and Engels (1969) Selected Works. Vol. 1. Moscow: Progress Publishers.

Mitchell A (2016) Beyond biodiversity and species: Problematizing extinction. Theory, Culture and Society 33(5): 23-42.

Morton A (2019) Fossil fuel exports make Australia one of the worst contributors to climate crisis. The Guardian, 8 July.

Muecke S (2004) Ancient \& Modern: Time, Culture and Indigenous Philosophy. Sydney: UNSW Press.

Muir C (2014) The Broken Promise of Agricultural Progress: An Environmental History. London: Routledge.

Murphy K (2017) Scott Morrison brings coal to question time: What fresh idiocy is this? The Guardian, 9 February.

National Alliance of Women's Organisation (2014) Womenifesto Indian Women's 11 Point Demand. Available at: https://csrindia.org/webpage/womanifesto.html (accessed 27 July 2020).

Neale T (2019) Bounds, governance, epistemes: A response to Manifesto Anthropoceno. Environmental Humanities 11(2): 485-492.

Neimanis A, Åsberg C and Hedrén J (2015) Four problems, four directions for environmental humanities: Toward critical posthumanities for the Anthropocene. Ethics \& The Environment 20(1): 67-97

Ocasio-Cortez A (2019) US House of Representatives 109 -116th Congress Recognizing the duty of the Federal Government to create a Green New Deal. Available at: https:/ocasio-cortez.house.gov/ sites/ocasio-cortez.house.gov/files/Resolution\%20on\%20a\%20Green\%20New\%20Deal.pdf (accessed 12 February 2019).

O’Gorman E (2014) Belonging. Environmental Humanities 5(1): 283-286.

Osborne N (2018) For still possible cities: A politics of failure for the politically depressed. Australian Geographer 50(2): 1-10.

Plumwood V (1991) Nature, self, and gender: Feminism, environmental philosophy, and the critique of rationalism. Hypatia 6(1): 3-23.

Plumwood V (2000) Integrating ethical frameworks for animals, humans, and nature: A critical feminist eco-socialist analysis. Ethics and the Environment 5(2): 285-322.

Plumwood V (2002a) Feminism and the Mastery of Nature. London: Routledge.

Plumwood V (2002b) Decolonising relationships with nature. PAN: Philosophy Activism Nature (2): 7.

Plumwood V (2005) Environmental Culture: The Ecological Crisis of Reason. London: Routledge.

Plumwood V (2008) Shadow places and the politics of dwelling. Australian Humanities Review 44: $139-150$.

Potter E and Magner B (2018) Murray-Mallee imaginaries: Towards the literary history of a region. Journal of the Association for the Study of Australian Literature 1(18): 1-18. https://openjournals. library.sydney.edu.au/index.php/JASAL/article/view/12537/11763

Probyn E (2016) Eating the Ocean. Durham, NC: Duke University Press.

Pulido L and De Lara J (2018) Re-imagining justice in environmental justice: Radical ecologies, decolonial thought and the Black Radical Tradition. Environment and Planning E 1(1-2): 76-98.

Rose A (2019) The climate change strike: From a student who was there. Chain Reaction (135): 12.

Rose DB (1996) Nourishing Terrains: Australian Aboriginal Views of Landscape and Wilderness. Canberra: Australian Heritage Commission.

Rose DB (2016) Dialogue. In: Gibson K, Rose DB and Fincher R (eds.) Manifesto for Living in the Anthropocene. Santa Barbara, CA: Punctum Books. pp. 127-132.

Rose DB, van Dooren T, Chrulew M, et al. (2012) Thinking through the environment, unsettling the humanities. Environmental Humanities 1(1): 1-5.

SBS News (2017) "Climate laggard": Australia is falling behind in global warming battle. Available at: https://www.sbs.com.au/news/climate-laggard-australia-is-falling-behind-in-global-warming-battle (accessed 9 November 2019).

Solanas V and Ronell A (2004) SCUM Manifesto. London: Verso.

Somerville M (2016) Deep mapping connections to country. In: Gibson K, Rose DB and Fincher R (eds.) Manifesto for Living in the Anthropocene. Santa Barbara, CA: Punctum Books. pp. 117-122. 
Sovereign Union (2015) Freedom Manifesto of demands. Available at: http://nationalunitygovern ment.org/content/aboriginal-sovereign-manifesto-demands (accessed 12 August 2019).

Sundberg J (2014) Decolonizing posthumanist geographies. Cultural Geographies 21(1): 33-47.

Sze J (2015) Environmental justice Anthropocene narratives: Sweet art, recognition, and representation. Resilience: A Journal of the Environmental Humanities 2(2), Available at: www.jstor.org/ stable/10.5250/resilience.2.2.010 (accessed 22 November 2020).

Taylor M (2019) Latest global school climate strikes expected to beat turnout record. Available at: https://www.theguardian.com/environment/2019/may/24/latest-global-school-climate-strikesexpected-to-beat-turnout-record (accessed 8 August 2019).

Todd Z (2016) An indigenous feminist's take on the ontological turn: 'Ontology' is just another word for colonialism. Journal of Historical Sociology 29(1): 4-22.

Tsing AL (2015) The Mushroom at the End of the World. Princeton, NJ: Princeton University Press.

Tsing AL, Swanson HA, Gan E, et al. (2017) Arts of Living on a Damaged Planet: Ghosts and Monsters of the Anthropocene. London: University of Minnesota Press.

Uluru Statement from the Heart (2017) Uluru Statement from the Heart. Available at: https://www. referendumcouncil.org.au/sites/default/files/2017-05/Uluru_Statement_From_The_Heart_0.PDF (accessed 8 August 2019).

van der Vaart G, van Hoven B and Huigen P (2018) Creative and arts-based research methods in academic research. Lessons from a participatory research project in the Netherlands. FORUM: Qualitative Social Research 2(19). http://www.qualitative-research.net/index.php/fqs/article/view/ 2961/4227 (accessed 12 August 2019).

Various (2019) The first fossil free welfare state? Swedish petro-dreams, resistances, and coastal transformations. Walkshop by the Shadow Places Network in Lysekil, 25-27 April 2019. Available at: www.theseedbox.se

VNS Matrix (1991) The cyperfeminist Manifesto for the 21st century. Available at: https://vnsmatrix. net/projects/the-cyberfeminist-manifesto-for-the-21st-century (accessed 27 July 2020).

Warriors of Aboriginal Resistance (WAR) (2014) Warriors of Aboriginal resistance MANIFESTO. Available at: https://issuu.com/brisbaneblacks/docs/war_manifesto_d91595ceee8754 (accessed 8 August 2019).

Weiss PA and Brueske M (2018) Feminist Manifestos: A Global Documentary Reader. New York: NYU Press.

Whyte K (2013) Justice forward: Tribes, climate adaptation and responsibility. Climatic Change 120(3): 117-130.

Whyte K (2017) Indigenous climate change studies: Indigenizing futures, decolonizing the Anthropocene. English Language Notes 55(1): 153-162.

Winkiel L (2006) The rhetoric of violence. Avant-Garde Manifestoes and the myths of racial community. In: The Invention of Politics in the European Avant-Garde (1906-1940). Leiden: Brill Rodopi, pp. 65-90.

Wright S, Lloyd K, Suchet-Pearson S, et al. (2012) Telling stories in, through and with country: Engaging with Indigenous and more-than-human methodologies at Bawaka, NE Australia. Journal of Cultural Geography 29(1): 39-60.

Yanoshevsky G (2009) Three decades of writing the manifesto: The making of a genre, Poetics Today 30(2): 257-286.

Yusoff K (2017) Geosocial strata. Theory, Culture \& Society 34(2-3): 105-127. 